\title{
The Psychological Impact of COVID-19 Pandemic on Graduating Class Students at the University of Gondar, Northwest Ethiopia
}

This article was published in the following Dove Press journal:

Psychology Research and Behavior Management

\author{
Enyew Getaneh Mekonen (iD) \\ Belayneh Shetie Workneh ${ }^{2}$ \\ Mohammed Seid $\mathrm{Ali}^{3}$ \\ Niguse Yigzaw Muluneh ${ }^{4}$ \\ 'Department of Surgical Nursing, School \\ of Nursing, College of Medicine and \\ Health Sciences, University of Gondar, \\ Gondar, Ethiopia; ${ }^{2}$ Department of \\ Emergency and Critical Care Nursing, \\ School of Nursing, College of Medicine \\ and Health Sciences, University of \\ Gondar, Gondar, Ethiopia; ${ }^{3}$ Department \\ of Pediatrics and Child Health Nursing, \\ School of Nursing, College of Medicine \\ and Health Sciences, University of \\ Gondar, Gondar, Ethiopia; ${ }^{4}$ Department \\ of Psychiatry, College of Medicine and \\ Health Sciences, University of Gondar, \\ Gondar, Ethiopia
}

Introduction: A poorly known contagious disease outbreak, like COVID-19, leads to unavoidable stress, fear, and anxiety. During the pandemic, University students suffer from adverse mental health outcomes resulted from the continuous spread of the disease, sensational media reporting, and implementation of social lockdown. Graduating class students are more affected due to cancellation and postponing of anticipated events such as exchange studies and graduation ceremonies. This study aimed to assess the prevalence and associated factors of anxiety, depression, and stress among graduating class students.

Methods: Institution-based cross-sectional study was conducted from November 10 to 30, 2020 at the University of Gondar. A simple random sampling technique was employed to select 350 students. Data were collected using a structured self-administered questionnaire, entered in EPI DATA version 3, analyzed using SPSS version 21, and presented in frequencies, percentages, tables, and graphs. Bivariable and multivariable analysis was investigated using a binary logistic regression model.

Results: The prevalence of stress, anxiety, and depression among graduating class students was $22.2 \%, 39.6 \%$, and $40.2 \%$ respectively. Living in an urban area, living with a family, sedentary lifestyle, unable to practice COVID-19 preventive measures, and having a contact history increases the risk of developing stress. Living in an urban area, substance use, sedentary lifestyle, and fear of infecting family increase the risk of developing anxiety. Students who came from an urban area, live with a family, study non-health departments, had confirmed cases in the family and did not perform physical exercise had higher odds of developing depression.

Conclusion: More than one-fifth, more than one-third, and nearly two-fifths of graduating students had stress, anxiety, and depression respectively. It is better to develop effective strategies and interventions, train students about self-protection, and establish a psychological crisis intervention team to minimize the psychological impact of the COVID-19 pandemic

Keywords: anxiety, COVID-19, depression, stress, graduating class students

\section{Introduction}

Coronavirus Disease 2019 (COVID-19) is a disease caused by a novel coronavirus (SARS-CoV-2) that emerged in a seafood and poultry market in the Chinese city of Wuhan in 2019. The World Health Organization (WHO) characterized the outbreak as a pandemic on March 11, 2020, as cases have been detected in most countries worldwide. ${ }^{1}$ As of October 30, 2020, there have been 45,608,024 laboratory-confirmed coronavirus cases, including 1,189,139 deaths worldwide according to Johns
Correspondence: Enyew Getaneh Mekonen Tel +251946607528

Email enyewgetaneh12@gmail.com
Psychology Research and Behavior Management 2021:14 109-122 
Hopkins University. The pandemic has interrupted the learning of more than one billion students in 129 countries around the world according to the United Nations Educational, Scientific, and Cultural Organization (UNESCO). ${ }^{2}$

The first case of COVID-19 was confirmed in Ethiopia on 13 March 2020 which was the first one to be reported since the beginning of the outbreak in China in December 2019. ${ }^{3}$ On 8 April 2020, the Council of Ministers declared a five-month-long state of emergency in response to the growing number of coronavirus cases, and schools, sporting events, and public gatherings were closed. ${ }^{4}$ According to the ministry of health, Ethiopia there were 95,789 COVID-19 reported cases and 1464 (1.53\%) deaths in Ethiopia until October 30, 2020.

The COVID-19 pandemic affects mental health and well-being in addition to physical health. ${ }^{5,6}$ University graduating class students are more affected psychologically by the pandemic due to cancellation and postponing of anticipated events such as exchange studies and graduation ceremonies. ${ }^{7}$ A poorly known contagious disease outbreak, like COVID-19, leads to unavoidable stress, fear, and anxiety. ${ }^{8}$ The mental well-being of university students can be negatively affected by shifting face-to-face classes to online, suspension of the semester-end final examinations, and unavailability of books, computers, and highspeed internet connection at home. ${ }^{9}$

During the pandemic, University students are at significant risk of adverse mental health outcomes resulted from the continuous spread of the disease, conspiracy theories, myths, and blame games, sensational media reporting of COVID-19, frustration and boredom, implementation of social lockdown with classmates, friends, and teachers, lack of personal space at home, and family financial loss due to lockdown. ${ }^{10}$ The careers of this years' university graduates may be seriously impacted due to the pandemic since they experience major interruptions in teaching and assessment in the final part of their studies, and late graduation. ${ }^{9}$

The pandemic has potentially affected students physically, academically, financially, and psychologically. In a short period, students' lives have dramatically changed as they have been asked to leave campus, adjust to new living circumstances, and adapt to online learning platforms. ${ }^{11}$ Different studies showed that the prevalence of depression, anxiety, and stress was high among university students. From studies conducted in Pakistan and Bangladesh, the prevalence was $34 \%$ and $82.4 \%$ for depression and $45 \%$ and $87.7 \%$ for anxiety respectively. ${ }^{10,12}$

One study in Nigeria indicated that the prevalence of anxiety and depression was $31.9 \%$ and $41.4 \%$ respectively. ${ }^{13}$ In Ethiopia, two studies reported that the prevalence of depression, anxiety, and stress was $21.2 \%$ and $77.2 \%, 27.7 \%$ and $71.8 \%$, and $32.5 \%$ and $48.5 \%$ respectively. ${ }^{14,15}$ Kinds of literature also indicated that age, sex, history of medical illness, living in a State/ Region with a high incidence of COVID-19, family income, having family members infected with the disease, the practice of preventive measures, and residence were determinants of depression, anxiety, and stress. ${ }^{10,12,14,15}$

The ongoing spread of COVID- 19, strict isolation measures, delays in starting school, and postponing graduation across the country influences the mental health of graduating class university students. As a result, estimating the psychological impact of the COVID-19 pandemic on graduating class students is important for health authorities to develop preventive strategies and effective treatment modalities to alleviate its negative outcome. Therefore, this study is intended to assess the prevalence and associated factors of depression, anxiety, and stress among graduating class students at the University of Gondar, northwest Ethiopia.

\section{Methods and Materials}

\section{Study Design and Period}

An institution-based cross-sectional study was conducted from November 10 to 30, 2020.

\section{Study Setting}

The study was conducted at the University of Gondar, Gondar, Ethiopia. The University of Gondar, until 2003 known as the Gondar College of Medical Sciences, is the oldest medical school in Ethiopia. Established as the Public Health College in 1954. It is located in northwest Ethiopia $750 \mathrm{~km}$ far from Addis Ababa, the capital of Ethiopia. In 2010, the university offered 42 undergraduate and 17 postgraduate programs. As of 2016, the University offers 56 undergraduate and 64 postgraduate. These are organized under the College of Medicine and Health Sciences, College of Business and Economics, College of Natural and Computational Sciences, College of Social Sciences and Humanities, and Faculty of Veterinary Medicine and Faculty of Agriculture, and three schools (School of Law, School of Technology, and School of 
Education). According to the information from the president's office, currently, there are 2546 Academic staff, 5473 Administrative staff, 41,730 undergraduate students, and 5497 postgraduate students at the University of Gondar. There are a total of 5396 graduating class students on the five campuses (source: University of Gondar Main Registrar Office).

\section{Participants of the Study}

Graduating class students at the University of Gondar and available during the data collection period were included in the study. Those graduating class students who were absent from the class during the data collection period were excluded from the study.

\section{Sample Size Determination and Sampling Procedure}

The sample size was calculated using the single population proportion formula by taking the estimated proportion of depression, anxiety, and stress among graduating class students: $21.2 \%, 27.7 \%$, and $32.5 \%$, respectively from a study conducted in southwest Ethiopia, ${ }^{14}$ 95\% confidence interval, and a 5\% margin of error and the largest number was taken. The final sample size was 350 after using the correction formula and adding a 10\% non-response rate. To select study participants from the five campuses, all campuses were listed down with their total number of graduating students. The proportional allocation formula was used to allocate the number of students to the five campuses. Then the sampling frame was prepared for each campus by having lists of students from the main registrar's office. Finally, the study subjects of each campus were selected using a simple random sampling technique.

\section{Operational Definitions Anxiety}

Participants who score below 8 on the Depression, Anxiety, and Stress Scale - 21 Items (DASS-21) were considered as having no anxiety and those who score 8 and above were considered as having anxiety. ${ }^{26}$

\section{Depression}

Participants who score below 10 on the Depression, Anxiety, and Stress Scale - 21 Items (DASS-21) were considered as having no depression and those who score 10 and above were considered as having depression. ${ }^{26}$

\section{Stress}

Participants who score below 15 on the Depression, Anxiety, and Stress Scale - 21 Items (DASS-21) were considered as having no stress and those who score 15 and above were considered as having stress. ${ }^{26}$

\section{Substance Use}

Use of chat, alcohol, cigarette smoking, or others at least once in the last three months.

\section{Perform Physical Activity}

Exercising or doing any kind of sports activity including walking at least $20 \mathrm{~min} /$ day. $^{25}$

\section{Data Collection Instruments and Procedures}

Data were collected using a structured pre-tested selfadministered questionnaire. The questionnaire contained 38 questions arranged into five sections; the first section contains six questions regarding the socio-demographic characteristics of the participants, the second section contains three questions regarding clinical related conditions of graduating students, the third section contains two behavioral related questions, the fourth section contains six personal related questions, and the fifth section contains 21 questions regarding the depression, anxiety, and stress status of graduating students. Depression, anxiety, and stress was measured using the Depression, Anxiety, and Stress Scale - 21 Items (DASS-21). The DASS-21 comprises 3 components: stress, anxiety, and depression. Each has 7 scales, and the final score of each part will be obtained by summing the scores of the related questions. Each item scores from 0 (did not apply to me at all) to 3 (applied to me very much). ${ }^{26}$ The reliability and validity of this questionnaire have been investigated. Its test-retest reliabilities for depression, anxiety, and stress were reported as $0.80,0.76$, and 0.77 , respectively. For examining the validity of this scale, the confirmatory factor analysis method and the main component technique were implemented. ${ }^{27}$ In the present study, the scale's face validity will be examined by the psychology and research methods expert. Data were collected with the help of five trained BSc nurse data collectors and three MSc nurse supervisors. A written guideline was given to the administrator of the questionnaire to assure that every graduating student received the same directions and information. During data collection data collectors and supervisors follow the recommended precautions to prevent COVID-19. 


\section{Data Processing and Analysis}

Data clean-up and cross-checking was done before analysis. Checked, cleaned, and coded data were entered into EPI DATA version 3 and exported to SPSS version 21 for analysis. Descriptive statistics like frequencies, percentages, mean and standard deviation, tables, and figures were used to present data. To assess the association between the different independent variables with the dependent variable, first, bivariable relationships between each independent variable and outcome variable was investigated using a binary logistic regression model. Those independent variables with a p-value $<0.2$ at the bivariable level were included in multivariable analysis to control potential confounding factors. After adjusting their effect on the outcome variable, those variables with a $\mathrm{p}$-value $<0.05$ with a $95 \%$ confidence interval were regarded as factors significantly associated.

\section{Data Quality Assurance}

The tool was pretested before the actual data collection time at Debre Tabor University which was not included in the study using $5 \%$ of the total sample size. Amendments on the instrument, such as unclear questions and ambiguous words made accordingly. The pretest was also be used to estimate how much time it takes to administer the entire questionnaire. The tool was first developed in the English language and translated to the Amharic language with back translation to English for consistency. The one-day training was given to data collectors and supervisors on the objective of the study, instrument, and data collection procedures by the principal investigators. Supervision was conducted by the principal investigators and supervisors. To ensure data quality, each data collector checked the questionnaire from each study participant for completeness daily. The supervisors and principal investigators review each questionnaire daily and checked for completeness.

\section{Results}

\section{Socio-Demographic Characteristics of Graduating Class Students}

A total of 338 graduate class students participated in this study, with a $96.6 \%$ response rate. More than half $(56.2 \%)$ of the respondents were male. The mean age of the respondents was $24.70 \pm 2.78 \mathrm{SD}$ years and more than half $(58.6 \%)$ of them fall in the age range of $20-24$ years. Concerning their residence more than half (57.7\%) of the respondents live in an urban area. More than three fourth $(77.5 \%)$ of the respondents were orthodox. Regarding their field of study majority (81.1\%) of them was other than the health field of studies (Table 1).

\section{Behavioral and Clinical-Related Characteristics of Graduating Class Students}

The majority (88.5\%) and (89.9\%) of the participants were not diagnosed with any chronic disease and had no family members/relatives confirmed or suspected for COVID-19 respectively. Three hundred eleven (92.0\%) of the participants had no history of mental disorders. More than threefourths $(81.1 \%)$ of the participants did not use a substance like chat, cigarette, and alcohol at least once in the last three months. More than two-thirds (68.0\%) of the respondents perform any kind of sports activity including walking for at least $20 \mathrm{~min}$ per day (Table 2).

\section{Personal Characteristics of Graduating Class Students}

Among the total 338 participants in the study, about 94.7\% of the students had good knowledge about preventive measures of COVID-19. The majority of the participants $(88.8 \%)$ in the study have a positive attitude towards the importance of the preventive measures of COVID-19. More than half $(53.0 \%)$ of the participants in the study have practiced COVID-19 preventive measures. More than

Table I Socio-Demographic Characteristics of Graduating Class Students in the University of Gondar, Northwest Ethiopia, 2020 $(\mathrm{N}=338)$

\begin{tabular}{|l|l|c|c|}
\hline Variables & Category & $\begin{array}{c}\text { Frequency } \\
(\mathbf{n = 3 3 8})\end{array}$ & $\begin{array}{c}\text { Percentage } \\
\mathbf{( 1 0 0 \% )}\end{array}$ \\
\hline Age & 20-24 years & 198 & 58.6 \\
& 25-29 years & 118 & 34.9 \\
& $\geq 30$ years & 22 & 6.5 \\
\hline \multirow{2}{*}{ Sex } & Male & 190 & 56.2 \\
& Female & 148 & 43.8 \\
\hline Residence & Rural & 143 & 42.3 \\
& Urban & 195 & 57.7 \\
\hline Religion & Orthodox & 262 & 77.5 \\
& Muslim & 29 & 8.6 \\
& Protestant & 38 & 11.2 \\
& Catholic & 9 & 2.7 \\
\hline \multirow{2}{*}{ Field of study } & Health & 64 & 18.9 \\
& Non-Health & 274 & 81.1 \\
\hline \multirow{2}{*}{ Living with family } & Yes & 294 & 87.0 \\
& No & 44 & 13.0 \\
\hline
\end{tabular}


Table 2 Behavioral and Clinical-Related Characteristics of Graduating Class Students in the University of Gondar, Northwest Ethiopia, $2020(\mathrm{~N}=338)$

\begin{tabular}{|l|l|l|l|}
\hline Variables & Category & $\begin{array}{l}\text { Frequency } \\
(\mathbf{n}=\mathbf{3 3 8})\end{array}$ & $\begin{array}{l}\text { Percentage } \\
\text { (100\%) }\end{array}$ \\
\hline $\begin{array}{l}\text { Diagnosed with } \\
\text { chronic disease }\end{array}$ & $\begin{array}{l}\text { Yes } \\
\text { No }\end{array}$ & $\begin{array}{l}39 \\
299\end{array}$ & $\begin{array}{l}11.5 \\
88.5\end{array}$ \\
\hline $\begin{array}{l}\text { Confirmed/suspected } \\
\text { case in the family }\end{array}$ & Yes & 34 & 10.1 \\
No & 304 & 89.9 \\
\hline $\begin{array}{l}\text { History of mental } \\
\text { disorders }\end{array}$ & Yes & 27 & 8.0 \\
\hline Substance use & Yes & 311 & 92.0 \\
\hline Perform physical & No & 274 & 18.9 \\
exercise & Yes & 230 & 68.0 \\
\hline
\end{tabular}

three-fifths $(62.4 \%)$ of the participants worried about infecting family members. Two hundred eighty-six (84.6\%) of the participants had no previous contact history with suspected or confirmed COVID-19 cases. Almost one-third (34.9\%) of the participants had a family member aged greater than 60 years (Table 3 ).

\section{Prevalence of Stress, Anxiety, and Depression}

The prevalence of stress, anxiety, and depression among graduate class students of the University of Gondar was $22.2 \%$ with a $95 \%$ CI $(17.8 \%, 26.6 \%), 39.6 \%$ with a $95 \%$

Table 3 Personal Characteristics of Graduating Class Students at the University of Gondar, Northwest Ethiopia, 2020 ( $N=338$ )

\begin{tabular}{|l|l|l|l|}
\hline Variables & Response & Frequency & $\begin{array}{l}\text { Percent } \\
\text { (\%) }\end{array}$ \\
\hline $\begin{array}{l}\text { Knowledge about COVID- } \\
19 \text { preventive measures }\end{array}$ & $\begin{array}{l}\text { Good } \\
\text { Poor }\end{array}$ & $\begin{array}{l}320 \\
18\end{array}$ & $\begin{array}{l}5.3 \\
94.7\end{array}$ \\
\hline $\begin{array}{l}\text { Attitude towards COVID- } \\
\text { 19 preventive measures }\end{array}$ & $\begin{array}{l}\text { Positive } \\
\text { Negative }\end{array}$ & 300 & 88.8 \\
\hline $\begin{array}{l}\text { Practicing COVID-19 } \\
\text { preventive measures }\end{array}$ & Yes & 179 & 53.0 \\
\hline $\begin{array}{l}\text { Fear of infecting family } \\
\text { members }\end{array}$ & Yes & 211 & 47.0 \\
\hline Nontact history & Yes & 127 & 62.4 \\
& No & 286 & 37.6 \\
\hline Living with a family aged $>$ & Yes & 118 & 34.9 \\
60 years old & No & 220 & 65.1 \\
\hline
\end{tabular}

CI $(34.3 \%, 45.6 \%)$, and $40.2 \%$ with a $95 \%$ CI $(34.8 \%$, $46.0 \%$ ) respectively (Figure 1). Fifty-five (16.3\%), 32.2\%, and $34.9 \%$ of the respondents faced difficulty relaxing to some degree, a considerable degree, and very much respectively. Nervous arousal was experienced by $28.1 \%$, $39.1 \%$, and $12.1 \%$ of them to some degree, a considerable degree, and very much respectively. Nearly three fourth (74.6\%), 72.5\%, 82.8\%, 65.7\%, and $50.6 \%$ of the study participants reported that they were easily upset, agitated, irritable, over-reactive, and impatient (Table 4). Two hundred eight $(61.6 \%), 62.1 \%, 40.5 \%$, and $34.6 \%$ of the respondents did not develop autonomic arousal, skeletal muscle effects, situational anxiety, and subjective experience of anxious affect respectively (Table 5). Nearly two thirds $(64.2 \%), 72.2 \%, 68 \%, 65.5 \%, 55 \%, 57.4 \%$, and $57.7 \%$ of the respondents develop dysphoria, hopelessness, devaluation of life, self-deprecation, lack of interest/involvement, anhedonia, and inertia respectively (Table 6).

\section{Factors Associated with Stress}

Variables like sex, residence, living with a family, the field of study, diagnosed with chronic disease, confirmed/suspected cases in the family, history of mental disorders, perform physical activity, attitude towards COVID-19 preventive measures, practicing COVID-19 preventive measures, fear of infecting family members, contact history with suspected or confirmed cases, and living with a person aged $>60$ years were found to be significantly associated with stress using bivariable logistic regression analysis. In multivariable logistic regression analysis, factors like residence, living with a family, perform physical exercise, practicing COVID-19 preventive measures, and contact history with suspected or confirmed cases were significantly associated with stress. Students who came from the rural residence were $56 \%$ times less likely to develop stress compared with students came from urban residence [AOR: $0.44 ; 95 \% \mathrm{CI}(0.24,0.80)]$. Those study participants who lived alone were $75 \%$ times less likely to experience stress compared with students who lived with their family [AOR: 0.25 ; $95 \%$ CI $(0.07,0.85)]$. Those students who did not perform physical activity were 2.2 times at a higher risk of developing stress compared with students who perform physical activity [AOR: 2.18; 95\% CI (1.20, 3.96)]. Students who did not practice COVID-19 preventive measures appropriately were nearly two times at a higher risk of developing stress compared with their counterparts [AOR: 1.94; 95\% CI $(1.08,3.50)]$. Students 


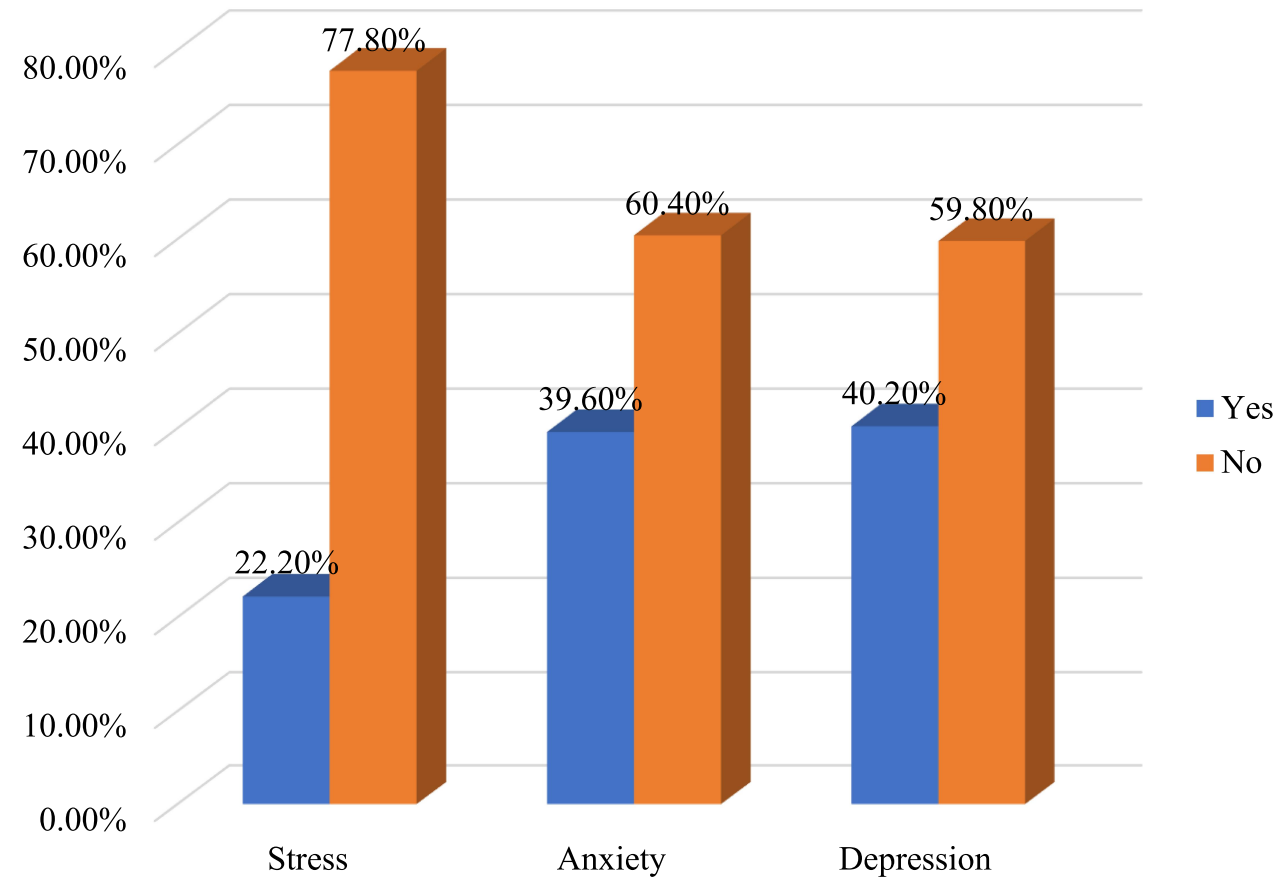

Figure I The prevalence of stress, anxiety, and depression among graduating class students at the University of Gondar, northwest Ethiopia, 2020 ( $\mathrm{n}=338$ ).

who had a contact history with suspected or confirmed cases were nearly seven times at a higher risk of developing stress compared with those who had not a contact history [AOR: 6.55; 95\% CI $(3.18,13.53)]$ (Table 7).

\section{Factors Associated with Anxiety}

Bivariable logistic regression analysis was carried out and the variables significantly associated with anxiety were; place of residence, the field of study, having a chronic disease, having a history of mental disorders, substance use, physical exercise, fear of infecting family members, confirmed/suspected cases in the family. Finally, multivariable logistic regression analysis was carried out to identify factors significantly associated with anxiety. The factors were the place of residence, substance use, physical exercise, and fear of infecting the family members. The odds of anxiety were $64 \%$ times less likely to occur among students who live in a rural area than in an urban area [AOR: $0.36 ; 95 \% \mathrm{CI}(0.22,0.61)]$. Those students who did not use a substance like a cigarette, chat or alcohol were $73 \%$ times less likely to develop anxiety as compared to students who use substances in the last three months [AOR: $0.27 ; 95 \%$ CI $(0.14-0.54)]$. Those students who did not perform physical exercise were two times more likely to develop anxiety as compared to their counterparts [AOR: 2.12; 95\% CI (1.24-3.62)]. Students who did not

Table 4 Responses of Graduating Class Students to the Stress Scale at the University of Gondar, Northwest Ethiopia, 2020 ( $n=338$ )

\begin{tabular}{|l|l|l|l|l|}
\hline \multirow{2}{*}{ Statements } & \multicolumn{3}{l|}{ Response (Frequency (Percentage)) } \\
\cline { 2 - 5 } & $\begin{array}{l}\text { Did Not Apply } \\
\text { to Me at All }\end{array}$ & $\begin{array}{l}\text { Applied to Me to } \\
\text { Some Degree }\end{array}$ & $\begin{array}{l}\text { Applied to Me to a } \\
\text { Considerable Degree }\end{array}$ & $\begin{array}{l}\text { Applied to Me } \\
\text { Very Much }\end{array}$ \\
\hline I found it hard to wind down & $56(16.6 \%)$ & $55(16.3 \%)$ & $109(32.2 \%)$ & $118(34.9 \%)$ \\
I tended to over-react to situations & $68(20.1 \%)$ & $95(28.1 \%)$ & $132(39.1 \%)$ & $43(12.1 \%)$ \\
I felt that I was using a lot of nervous energy & $86(25.4 \%)$ & $103(30.5 \%)$ & $69(20.4 \%)$ & $80(23.7 \%)$ \\
I found myself getting agitated & $93(27.5 \%)$ & $61(18.0 \%)$ & $84(24.9 \%)$ & $100(29.6 \%)$ \\
I found it difficult to relax & $58(17.2 \%)$ & $76(22.5 \%)$ & $92(27.2 \%)$ & $112(33.1 \%)$ \\
I was intolerant of anything that kept me from & $116(34.3 \%)$ & $93(27.5 \%)$ & $75(22.2 \%)$ & $54(16.0 \%)$ \\
getting on with what I was doing & & $92(27.2 \%)$ & $30(8.9 \%)$ & $49(14.5 \%)$ \\
I felt that I was rather touchy & $167(49.4 \%)$ & 92 & \\
\hline
\end{tabular}


Table 5 Responses of Graduating Class Students to the Anxiety Scale at the University of Gondar, Northwest Ethiopia, 2020 ( $\mathrm{n=338)}$

\begin{tabular}{|c|c|c|c|c|}
\hline \multirow[t]{2}{*}{ Statements } & \multicolumn{4}{|c|}{ Response (Frequency (Percentage)) } \\
\hline & $\begin{array}{l}\text { Did Not } \\
\text { Apply to Me } \\
\text { at All }\end{array}$ & $\begin{array}{l}\text { Applied to Me } \\
\text { to Some } \\
\text { Degree }\end{array}$ & $\begin{array}{l}\text { Applied to Me to a } \\
\text { Considerable } \\
\text { Degree }\end{array}$ & $\begin{array}{l}\text { Applied to } \\
\text { Me Very } \\
\text { Much }\end{array}$ \\
\hline I was aware of the dryness of my mouth & $196(58.0 \%)$ & $69(20.4 \%)$ & $37(10.9 \%)$ & $36(10.7 \%)$ \\
\hline $\begin{array}{l}\text { I experienced breathing difficulty (e.g. excessively rapid breathing, breathlessness } \\
\text { in the absence of physical exertion) }\end{array}$ & $220(65.1 \%)$ & $57(16.9 \%)$ & $39(11.5 \%)$ & $22(6.5 \%)$ \\
\hline I experienced trembling (e.g. in the hands) & $210(62.1 \%)$ & 71 (2I.0\%) & $32(9.5 \%)$ & $25(7.4 \%)$ \\
\hline I was worried about situations in which I might panic and make a fool of myself & $120(35.5 \%)$ & $101(29.9 \%)$ & 65 (19.2\%) & $52(15.4 \%)$ \\
\hline I felt I was close to panic & $136(40.2 \%)$ & $74(21.9 \%)$ & $80(23.7 \%)$ & $48(14.2 \%)$ \\
\hline $\begin{array}{l}\text { I was aware of the action of my heart in the absence of physical exertion (e.g. } \\
\text { sense of heart rate increase, heart missing a beat) }\end{array}$ & $155(45.9 \%)$ & 91 (26.9\%) & $60(17.8 \%)$ & $32(9.5 \%)$ \\
\hline I felt scared without any good reason & $117(34.6 \%)$ & $73(21.6 \%)$ & $89(26.3 \%)$ & $59(17.5 \%)$ \\
\hline
\end{tabular}

Table 6 Responses of Graduating Class Students to the Depression Scale at the University of Gondar, Northwest Ethiopia, 2020 $(n=338)$

\begin{tabular}{|c|c|c|c|c|}
\hline \multirow[t]{2}{*}{ Statements } & \multicolumn{4}{|c|}{ Response (Frequency (Percentage)) } \\
\hline & $\begin{array}{l}\text { Did Not Apply } \\
\text { to Me at All }\end{array}$ & $\begin{array}{l}\text { Applied to Me to } \\
\text { Some Degree }\end{array}$ & $\begin{array}{l}\text { Applied to Me to a } \\
\text { Considerable Degree }\end{array}$ & $\begin{array}{l}\text { Applied to Me } \\
\text { Very Much }\end{array}$ \\
\hline I could not seem to experience any positive feeling at all & $121(35.8 \%)$ & $99(29.3 \%)$ & $70(20.7 \%)$ & $48(14.2 \%)$ \\
\hline I found it difficult to work up the initiative to do things & $94(27.8 \%)$ & $76(22.5 \%)$ & $96(28.4 \%)$ & $72(21.3 \%)$ \\
\hline I felt that I had nothing to look forward to & $108(32.0 \%)$ & 81 (24.0\%) & $66(19.5 \%)$ & $83(24.6 \%)$ \\
\hline I felt down-hearted and blue & 116 (34.5\%) & $74(21.9 \%)$ & $73(21.6 \%)$ & $75(22.2 \%)$ \\
\hline I was unable to become enthusiastic about anything & $152(45.0 \%)$ & $92(27.2 \%)$ & $52(15.4 \%)$ & $42(12.4 \%)$ \\
\hline I felt I was not worth much as a person & $144(42.6 \%)$ & $86(25.4 \%)$ & $60(17.8 \%)$ & $48(14.2 \%)$ \\
\hline I felt that life was meaningless & $143(42.3 \%)$ & $67(19.8 \%)$ & $53(15.7 \%)$ & $75(22.2 \%)$ \\
\hline
\end{tabular}

worry about family members who could be infected were $49 \%$ times less likely to develop anxiety as compared to those who worried [AOR: $0.51 ; 95 \%$ CI $(0.31-0.87)]$ (Table 8).

\section{Factors Associated with Depression}

In bivariable logistic regression analysis, the following variables were found to be significantly associated with depression. Residence, living with family, the field of study, having a chronic disease, having suspected/infected relatives with COVID-19, history of mental disorders, substance use, physical activity, and contact history. Residence, living with a family, the field of study, having suspected/infected relatives with COVID-19, and physical exercise were factors significantly associated with depression using multivariable logistic regression. Students who live in the rural area were $45 \%$ times less likely to develop depression compared with those living in urban areas [AOR: $0.55,95 \% \mathrm{CI}(0.33,0.89)]$. Those students staying with their families were nearly four times at a higher risk of developing depression compared with students staying alone [AOR: 4.06, 95\% CI $(1.54,10.73)$ ]. Graduating students who study in health science were $58 \%$ times less likely to develop depression compared to students who study non-health departments [AOR: $0.42,95 \% \mathrm{CI}$ $(0.21,0.84)]$. Having suspected or infected cases in the family/relatives increase the risk of developing depression by nearly 3.5 times [AOR: $3.47,95 \%$ CI $(1.10,10.95)]$. Those students who did not perform physical exercise were nearly two times at higher risk of developing depression compared with those who perform physical exercise [AOR: 1.74; 95\% CI (1.04, 2.93)] (Table 9).

\section{Discussion}

After the first onset of the COVID-19 in china Wuhan city, it has had various effects on the Globe. The closure of universities due to the virus caused students to drop out of school. Especially it has a huge psychological impact on graduate class students. The current study revealed that $22.2 \%, 39.6 \%$, and $40.2 \%$ of the respondents experienced stress, anxiety, 
Table 7 Bivariable and Multivariable Logistic Regression Analysis of Factors Associated with Stress Among Graduating Class Students in the University of Gondar, Northwest Ethiopia, $2020(\mathrm{~N}=338)$

\begin{tabular}{|c|c|c|c|c|c|c|}
\hline \multicolumn{2}{|l|}{ Variables } & \multicolumn{2}{|c|}{ Stress } & \multicolumn{2}{|l|}{ OR with $95 \% \mathrm{Cl}$} & \multirow[t]{2}{*}{ P-value } \\
\hline & & Yes & No & Crude & Adjusted & \\
\hline Sex & $\begin{array}{l}\text { Female } \\
\text { Male }\end{array}$ & $\begin{array}{l}26 \\
49\end{array}$ & $\begin{array}{l}122 \\
141\end{array}$ & $\begin{array}{l}0.6 \mathrm{I}(0.36,1.05) \\
\mathrm{I}\end{array}$ & $\begin{array}{l}0.60(0.33,1.11) \\
1\end{array}$ & 0.106 \\
\hline Residence & $\begin{array}{l}\text { Urban } \\
\text { Rural }\end{array}$ & $\begin{array}{l}36 \\
39\end{array}$ & $\begin{array}{l}159 \\
104\end{array}$ & $\begin{array}{l}0.60(0.36,1.0 I) \\
I\end{array}$ & $\begin{array}{l}0.44(0.24,0.80)^{*} \\
\text { I }\end{array}$ & 0.007 \\
\hline Living with a family & $\begin{array}{l}\text { Yes } \\
\text { No }\end{array}$ & $\begin{array}{l}71 \\
4\end{array}$ & $\begin{array}{l}223 \\
40\end{array}$ & $\begin{array}{l}3.18(1.10,9.21) \\
1\end{array}$ & $\begin{array}{l}0.25(0.07,0.85)^{*} \\
\text { I }\end{array}$ & 0.026 \\
\hline Field of study & $\begin{array}{l}\text { Non-health } \\
\text { Health }\end{array}$ & $\begin{array}{l}69 \\
6\end{array}$ & $\begin{array}{l}205 \\
58\end{array}$ & $\begin{array}{l}3.25(1.35,7.87) \\
1\end{array}$ & $\begin{array}{l}0.39(0.15,1.00) \\
1\end{array}$ & 0.050 \\
\hline Chronic disease & $\begin{array}{l}\text { Yes } \\
\text { No }\end{array}$ & $\begin{array}{l}16 \\
59\end{array}$ & $\begin{array}{l}23 \\
240\end{array}$ & $\begin{array}{l}2.83(I .4 I, 5.69) \\
I\end{array}$ & $\begin{array}{l}\text { I.79 }(0.79,4.06) \\
\text { I }\end{array}$ & 0.162 \\
\hline Confirmed cases in the family & $\begin{array}{l}\text { Yes } \\
\text { No }\end{array}$ & $\begin{array}{l}17 \\
58\end{array}$ & $\begin{array}{l}17 \\
246\end{array}$ & $\begin{array}{l}4.24(2.04,8.8 I) \\
I\end{array}$ & $\begin{array}{l}0.86(0.27,2.73) \\
\text { I }\end{array}$ & 0.791 \\
\hline History of mental disorders & $\begin{array}{l}\text { Yes } \\
\text { No }\end{array}$ & $\begin{array}{l}10 \\
65\end{array}$ & $\begin{array}{l}17 \\
246\end{array}$ & $\begin{array}{l}2.23(0.97,5.09) \\
I\end{array}$ & $\begin{array}{l}\mathrm{I} .0 \mathrm{I}(0.27,3.83) \\
\mathrm{I}\end{array}$ & 0.991 \\
\hline Physical activity & $\begin{array}{l}\text { No } \\
\text { Yes }\end{array}$ & $\begin{array}{l}35 \\
40\end{array}$ & $\begin{array}{l}73 \\
190\end{array}$ & $\begin{array}{l}2.28(1.34,3.86) \\
I\end{array}$ & $\begin{array}{l}2.18(1.20,3.96)^{*} \\
1\end{array}$ & 0.010 \\
\hline Attitude & $\begin{array}{l}\text { Good } \\
\text { Poor }\end{array}$ & $\begin{array}{l}63 \\
12\end{array}$ & $\begin{array}{l}237 \\
26\end{array}$ & $\begin{array}{l}\text { I } \\
0.58(0.28,1.21)\end{array}$ & $\begin{array}{l}\text { I } \\
1.22(0.47,3.19)\end{array}$ & 0.682 \\
\hline Practice & $\begin{array}{l}\text { Poor } \\
\text { Good }\end{array}$ & $\begin{array}{l}45 \\
30\end{array}$ & $\begin{array}{l}114 \\
149\end{array}$ & $\begin{array}{l}1.96(1.16,3.31) \\
1\end{array}$ & $\begin{array}{l}1.94(1.08,3.50)^{*} \\
\mathrm{I}\end{array}$ & 0.027 \\
\hline Fear of infecting family members & $\begin{array}{l}\text { Yes } \\
\text { No }\end{array}$ & $\begin{array}{l}52 \\
23\end{array}$ & $\begin{array}{l}159 \\
104\end{array}$ & $\begin{array}{l}1.48(0.85,2.56) \\
I\end{array}$ & $\begin{array}{l}1.72(0.93,3.20) \\
I\end{array}$ & 0.086 \\
\hline Contact history & $\begin{array}{l}\text { Yes } \\
\text { No }\end{array}$ & $\begin{array}{l}27 \\
48\end{array}$ & $\begin{array}{l}25 \\
238\end{array}$ & $\begin{array}{l}5.36(2.86,10.02) \\
1\end{array}$ & $\begin{array}{l}6.55(3.18,13.53)^{*} \\
\text { I }\end{array}$ & $<0.001$ \\
\hline Living with a person aged $>60$ years & $\begin{array}{l}\text { Yes } \\
\text { No }\end{array}$ & $\begin{array}{l}38 \\
37\end{array}$ & $\begin{array}{l}80 \\
183\end{array}$ & $\begin{array}{l}2.35(1.39,3.97) \\
\text { । }\end{array}$ & $\begin{array}{l}\text { I.64 (0.9I, 2.98) } \\
\text { । }\end{array}$ & 0.102 \\
\hline
\end{tabular}

Note: *Statistically significant at $\mathrm{p}$-value $<0.05$.

and depression respectively in response to the COVID-19 pandemic. This result suggests that the coronavirus has a significant psychological impact on graduate class students who need mental health intervention.

The prevalence of stress among graduating class university students in the current study was $22.2 \%$. This finding was lower than studies conducted in Bench-Sheko Zone, South-west Ethiopia (32.5\%), Dessie town, Ethiopia (48.5\%), United States (71\%), China (67.1\%), Spain (28.1\%), Canada (30\%), and Malaysia (28.9\%). ${ }^{14,15,18,21-23,25}$ The possible justification for the lower prevalence of stress in this study might be due to the difference in time of the study.
Currently, students can get a variety of information regarding the virus than the information they obtained at the beginning of the pandemic. Returning of the students to the university and start learning, the approval and administration of vaccines for COVID19 , and the increased number of patients who recovered from the disease than individuals who newly diagnosed and died might also contribute to the decrement of stress among students in the current study compared with the previous studies. The previous studies were conducted when students were at home and at the beginning of the pandemic which may result in a high prevalence of stress among students. 
Table 8 Bivariable and Multivariable Logistic Regression Analysis of Factors Associated with Anxiety Among Graduating Class Students in the University of Gondar, Northwest Ethiopia, 2020 (N=338)

\begin{tabular}{|c|c|c|c|c|c|c|}
\hline \multirow[t]{2}{*}{ Variables } & \multirow[t]{2}{*}{ Response } & \multicolumn{2}{|c|}{ Anxiety } & \multicolumn{2}{|c|}{ OR with $95 \% \mathrm{Cl}$} & \multirow[t]{2}{*}{ P-value } \\
\hline & & Yes & No & Crude & Adjusted & \\
\hline Sex & $\begin{array}{l}\text { Female } \\
\text { Male }\end{array}$ & $\begin{array}{l}58 \\
76\end{array}$ & $\begin{array}{l}90 \\
144\end{array}$ & $\begin{array}{l}1.22(0.66-1.60) \\
1\end{array}$ & $\begin{array}{l}1.17(0.69-1.97) \\
1\end{array}$ & 0.552 \\
\hline Residence & $\begin{array}{l}\text { Urban } \\
\text { Rural }\end{array}$ & $\begin{array}{l}61 \\
73\end{array}$ & $\begin{array}{l}134 \\
70\end{array}$ & $\begin{array}{l}0.44(0.27-0.68) \\
\text { । }\end{array}$ & $\begin{array}{l}0.36(0.22-0.61)^{*} \\
1\end{array}$ & $<0.001$ \\
\hline Living with family & $\begin{array}{l}\text { Yes } \\
\text { No }\end{array}$ & $\begin{array}{l}122 \\
12\end{array}$ & $\begin{array}{l}172 \\
32\end{array}$ & $\begin{array}{l}1.89(0.93-3.82) \\
1\end{array}$ & $\begin{array}{l}0.66(0.29-1.51) \\
1\end{array}$ & 0.334 \\
\hline Field of study & $\begin{array}{l}\text { Non health } \\
\text { Health }\end{array}$ & $\begin{array}{l}117 \\
17\end{array}$ & $\begin{array}{l}157 \\
47\end{array}$ & $\begin{array}{l}2.06(1.26-3.77) \\
1\end{array}$ & $\begin{array}{l}0.49(0.23-1.07) \\
1\end{array}$ & 0.071 \\
\hline Chronic disease & $\begin{array}{l}\text { Yes } \\
\text { No }\end{array}$ & $\begin{array}{l}23 \\
111\end{array}$ & $\begin{array}{l}16 \\
188\end{array}$ & $\begin{array}{l}2.43(1.23-4.80) \\
1\end{array}$ & $\begin{array}{l}0.86(0.35-2.10) \\
1\end{array}$ & 0.753 \\
\hline Confirmed cases in the family & $\begin{array}{l}\text { Yes } \\
\text { No }\end{array}$ & $\begin{array}{l}23 \\
111\end{array}$ & $\begin{array}{l}11 \\
193\end{array}$ & $\begin{array}{l}3.63(1.71-7.73) \\
1\end{array}$ & $\begin{array}{l}1.59(0.52-4.88) \\
1\end{array}$ & 0.921 \\
\hline History of mental disorders & $\begin{array}{l}\text { Yes } \\
\text { No }\end{array}$ & $\begin{array}{l}17 \\
117\end{array}$ & $\begin{array}{l}10 \\
194\end{array}$ & $\begin{array}{l}2.82(1.23-6.36) \\
1\end{array}$ & $\begin{array}{l}0.45(0.15-1.36) \\
1\end{array}$ & 0.163 \\
\hline Substance use & $\begin{array}{l}\text { Yes } \\
\text { No }\end{array}$ & $\begin{array}{l}41 \\
93\end{array}$ & $\begin{array}{l}23 \\
181\end{array}$ & $\begin{array}{l}3.46(1.96-6.13) \\
1\end{array}$ & $\begin{array}{l}0.27(0.14-0.54)^{*} \\
1\end{array}$ & $<0.001$ \\
\hline Physical exercise & $\begin{array}{l}\text { No } \\
\text { Yes }\end{array}$ & $\begin{array}{l}53 \\
81\end{array}$ & $\begin{array}{l}55 \\
149\end{array}$ & $\begin{array}{l}1.77(1.11,2.82) \\
1\end{array}$ & $\begin{array}{l}2.12(1.24-3.62)^{*} \\
1\end{array}$ & 0.006 \\
\hline Fear of infecting family members & $\begin{array}{l}\text { Yes } \\
\text { No }\end{array}$ & $\begin{array}{l}95 \\
39\end{array}$ & $\begin{array}{l}116 \\
88\end{array}$ & $\begin{array}{l}1.85(1.12-2.94) \\
1\end{array}$ & $\begin{array}{l}0.51(0.31-0.87)^{*} \\
1\end{array}$ & 0.013 \\
\hline Contact history & $\begin{array}{l}\text { Yes } \\
\text { No }\end{array}$ & $\begin{array}{l}25 \\
109\end{array}$ & $\begin{array}{l}27 \\
177\end{array}$ & $\begin{array}{l}1.50(0.83-2.72) \\
1\end{array}$ & $\begin{array}{l}1.14(0.54-2.40) \\
1\end{array}$ & 0.714 \\
\hline Living with a person aged $>60$ years old & $\begin{array}{l}\text { Yes } \\
\text { No }\end{array}$ & $\begin{array}{l}53 \\
81\end{array}$ & $\begin{array}{l}65 \\
139\end{array}$ & $\begin{array}{l}1.40(0.89-2.21) \\
1\end{array}$ & $\begin{array}{l}0.79(0.47-1.33) \\
1\end{array}$ & 0.382 \\
\hline
\end{tabular}

Note: *Statistically significant at $\mathrm{p}$-value $<0.05$.

The prevalence of anxiety in this study was $39.6 \%$. This finding was higher than studies conducted in BenchSheko Zone, southwest Ethiopia; $27.7 \%,{ }^{14}$ China $24.9 \%,{ }^{16}$ Chinese university students; $15.43 \%,{ }^{19}$ another study in China; $7.7 \%{ }^{20}$ and Spain; $21.34 \% .^{22}$ This discrepancy might be due to poor socioeconomic status in Ethiopia which determines the body defense mechanism of preventing coronavirus infection, in developing countries as compared to a developed country like China. Studies provide strong evidence that socioeconomic status impacts the development of mental illness directly, as well as indirectly through its association with adverse economic stressful conditions among lower-income groups. ${ }^{30}$ This might be also in China the health care system is well developed and advanced than Ethiopia so that anxiety due to fear of infection was higher in Ethiopia than in China. The prevalence of anxiety in this study was comparable with a study conducted in Italy; $34.4 \%,{ }^{17}$ Canada; $35 \%,{ }^{23}$ and 40.1\% conducted in multicounty: Oman, Saudi Arabia, Jordan, Iraq, United Arab Emirates, and Egypt. ${ }^{31}$

On the other hand, the prevalence of anxiety among graduating class students in this study was lower than studies conducted in Dessie town, Amhara region, Ethiopia; 71.8\%, ${ }^{15}$ Addis Ababa Ethiopia; 51.6\%, ${ }^{32}$ and Bangladesh $87.7 \% .^{12}$ This discrepancy might be due to the higher population density in Addis Ababa than Gondar, so that keeping a social distance is difficult in Addis Ababa than in Gondar, Ethiopia. Also, the prevalence of coronavirus cases was higher in Addis Ababa than in Gondar, due to these reason students in Gondar develops slightly lower than Addis Ababa. Urban living environments are associated with higher rates of prescription for psychotropic medication for anxiety, depression, and psychosis. ${ }^{33}$ 
Table 9 Bivariable and Multivariable Logistic Regression Analysis of Factors Associated with Depression Among Graduating Class Students in the University of Gondar, Northwest Ethiopia, $2020(\mathrm{~N}=338)$

\begin{tabular}{|c|c|c|c|c|c|c|}
\hline \multicolumn{2}{|l|}{ Variables } & \multicolumn{2}{|c|}{ Depression } & \multicolumn{2}{|l|}{ OR with $95 \% \mathrm{Cl}$} & \multirow[t]{2}{*}{ P-value } \\
\hline & & Yes & No & Crude & Adjusted & \\
\hline Residence & $\begin{array}{l}\text { Urban } \\
\text { Rural }\end{array}$ & $\begin{array}{l}66 \\
70\end{array}$ & $\begin{array}{l}129 \\
73\end{array}$ & $\begin{array}{l}0.53(0.34,0.83) \\
\text { I }\end{array}$ & $\begin{array}{l}0.55(0.33,0.89)^{*} \\
\text { I }\end{array}$ & 0.016 \\
\hline Living with a family & $\begin{array}{l}\text { Yes } \\
\text { No }\end{array}$ & $\begin{array}{l}129 \\
7\end{array}$ & $\begin{array}{l}165 \\
37\end{array}$ & $\begin{array}{l}4.13(1.78,9.57) \\
1\end{array}$ & $\begin{array}{l}4.06(1.54,10.73)^{*} \\
\text { । }\end{array}$ & 0.005 \\
\hline Field of study & $\begin{array}{l}\text { Health } \\
\text { Non-health }\end{array}$ & $\begin{array}{l}14 \\
122\end{array}$ & $\begin{array}{l}50 \\
152\end{array}$ & $\begin{array}{l}\text { I } \\
0.35(0.18,0.66)\end{array}$ & $\begin{array}{l}\text { I } \\
0.42(0.21,0.84)^{*}\end{array}$ & 0.015 \\
\hline Chronic disease & $\begin{array}{l}\text { Yes } \\
\text { No }\end{array}$ & $\begin{array}{l}24 \\
112\end{array}$ & $\begin{array}{l}15 \\
187\end{array}$ & $\begin{array}{l}2.67(1.35,5.31) \\
1\end{array}$ & $\begin{array}{l}1.04(0.43,2.54) \\
\mathrm{I}\end{array}$ & 0.928 \\
\hline Suspected/infected relatives & $\begin{array}{l}\text { Yes } \\
\text { No }\end{array}$ & $\begin{array}{l}28 \\
108\end{array}$ & $\begin{array}{l}6 \\
196\end{array}$ & $\begin{array}{l}8.47(3.40,21.09) \\
\text { । }\end{array}$ & $\begin{array}{l}3.47(1.10,10.95)^{*} \\
\text { I }\end{array}$ & 0.034 \\
\hline History of mental disorders & $\begin{array}{l}\text { Yes } \\
\text { No }\end{array}$ & $\begin{array}{l}19 \\
117\end{array}$ & $\begin{array}{l}8 \\
194\end{array}$ & $\begin{array}{l}3.94(1.67,9.28) \\
1\end{array}$ & $\begin{array}{l}3.07(0.92,10.27) \\
\text { I }\end{array}$ & 0.068 \\
\hline Substance use & $\begin{array}{l}\text { Yes } \\
\text { No }\end{array}$ & $\begin{array}{l}31 \\
105\end{array}$ & $\begin{array}{l}33 \\
169\end{array}$ & $\begin{array}{l}\mathrm{I} .5 \mathrm{I}(0.85,2.6 \mathrm{I}) \\
\mathrm{I}\end{array}$ & $\begin{array}{l}0.99(0.50,1.96) \\
1\end{array}$ & 0.978 \\
\hline Physical exercise & $\begin{array}{l}\text { Yes } \\
\text { No }\end{array}$ & $\begin{array}{l}82 \\
54\end{array}$ & $\begin{array}{l}148 \\
54\end{array}$ & $\begin{array}{l}\text { I } \\
0.55(0.35,0.88)\end{array}$ & $\begin{array}{l}\text { I } \\
\text { I.74(I.04, 2.93)* }\end{array}$ & 0.036 \\
\hline Contact history & $\begin{array}{l}\text { Yes } \\
\text { No }\end{array}$ & $\begin{array}{l}31 \\
105\end{array}$ & $\begin{array}{l}21 \\
181\end{array}$ & $\begin{array}{l}2.55(1.39,4.66) \\
1\end{array}$ & $\begin{array}{l}1.59(0.69,3.68) \\
\text { । }\end{array}$ & 0.280 \\
\hline
\end{tabular}

Note: *Statistically significant at $\mathrm{p}$-value $<0.05$.

The prevalence of depression in this study was $40.2 \%$. This finding was higher than studies conducted in Italy; $27.8 \%,{ }^{17}$ China, $12.2 \%,{ }^{20}$ Spanish; $34.19 \%,{ }^{22}$ and Canada $30 \%{ }^{23}$ This might be due to the difference in implementing preventive measures, getting access to preventive equipment, information technology, and health system. According to the World Health Organization, developing countries like Africa could be severely affected by the virus, which leads to more frustration and depression in developing countries. However, this finding was lower than studies conducted in Bangladesh; $82.4 \%,{ }^{12}$ China, 46.55\%, ${ }^{21}$ and Dessie Ethiopia; 77.2\%. ${ }^{15}$ The difference might be due to the difference in the study period. Even though the COVID-19 has been found active and lethal still, humans' fear has been declining over time. As soon as the COVID-19 virus detected there was a restriction in routine activities like lockdown and closing schools including universities and colleges and there was no hint about vaccines which leads humans to more frustration. On the other hand, the previous studies were done at a time when the students were out of school while this study is conducted after the students returned to the school.
Residence, living with a family, perform physical activity, practicing COVID-19 preventive measures, and contact history with suspected or confirmed cases were the factors significantly associated with stress. Students who came from rural residences were $56 \%$ times less likely to develop stress compared with students who came from the urban residence. This finding was supported by studies conducted in Dessie town Ethiopia and China. ${ }^{15,16}$ This might be due to the high prevalence of COVID-19 in urban residences than the rural. Students who live in an urban area may have a higher risk of developing stress than students who live in a rural part of the country as most positive cases were detected in the urban area. Moreover, repeated media exposure and obtaining daily information regarding the pandemic might also expose them to stress. Students who lived alone were $75 \%$ times less likely to experience stress compared with students who lived with their families. This finding was supported by a study conducted in the United States. ${ }^{18}$ This might be due to the pandemic increased the level of fear and worry about infecting their families. Students may be worried more if there are more vulnerable family members like 
older adults, with existing health problems, and pregnant mothers. They might also worry about their family members whose occupation increased their risk of exposure to the virus-like essential and health care workers which contribute to an increased level of stress.

Those students who did not perform physical exercise were 2.2 times at a higher risk of developing stress compared with students who perform physical exercise. This finding was supported by studies conducted in Turkey, the United Kingdom, and Brazil. ${ }^{34-36}$ This might be due to engaging in physical activity regularly is a healthy habit and a protective factor against diseases and harmful risk behaviors. Performing physical activity provides several benefits like improving self-esteem and body image, decreasing stress and nervous tension, improving motor balance, and favoring social relatedness. ${ }^{37}$ Students who did not perform physical activity can not relate and socialize with their peers simply by belonging to a team or sports club which increases the risk of developing stress.

Similarly, students who did not practice COVID-19 preventive measures appropriately were nearly two times at a higher risk of developing stress compared with their counterparts. This finding was supported by a study conducted in Dessie town, Ethiopia. ${ }^{15}$ This might be due to preventive measures are key to reducing COVID-19 morbidity and mortality. As a result, students who implement COVID-19 preventive measures like wearing a mask, hand washing, and physical distancing appropriately become more confident and less exposed to stress than students who did not implement it. Also, students who had a contact history with suspected or confirmed cases were nearly seven times at a higher risk of developing stress compared with those who had not a contact history. This finding was supported by a study conducted in Mexico. ${ }^{38}$ This might be due to fear of being infected with COVID-19 and what could happen can be overwhelming and cause strong emotions. Students who had contact with COVID-19 suspected and positive patients might worry about their health and develop stress.

Among the factors that affect the prevalence of anxiety in this study was the place of residence. Graduating students who came from the urban area had higher anxiety as compared to those students that came from the rural area. This finding was supported by studies conducted in Bangladesh ${ }^{12}$ and China. ${ }^{16}$ This might be due to one of the transmissions of coronavirus from an infected person to an uninfected person is physical contact. So people living in the urban area are more condensed than the rural area and rural areas are more scattered than the urban area. Another factor significantly associated with the prevalence of anxiety in this study was performing physical exercise for at least $20 \mathrm{~min}$ per day. Those students who did not perform the physical exercise for at least 20 min per day were almost two times more likely to develop anxiety as compared to those who did perform physical exercise regularly. This finding was supported by a study conducted in Bangladesh. ${ }^{12}$ The possible reason might be due to regular exercise may help ease depression and anxiety by releasing feel-good endorphins, natural cannabis-like brain chemicals (endogenous cannabinoids), and other natural brain chemicals that can enhance the sense of well-being.

The graduating students who worried about family members who could be infected were more likely to develop anxiety in comparison with their counterparts. This finding was supported by studies conducted in Bench-Sheko Zone, South-west Ethiopia, ${ }^{14}$ and Guangzhou, China. ${ }^{20}$ This might be due to the greatest fear of students resulted from the possibility of infecting family members during the pandemic. Substance use like cigarettes, alcohol, or chat was one of the factors associated with anxiety in this study. The risk of developing anxiety was higher among substance users as compared to non-substance users. The possible reason might be due to some substances may help to ease anxiety in the shortterm, their effects are temporary, and the use of these substances can create a psychological or physiological dependence, which will cause or worsen other life problems and will ultimately exacerbate anxiety.

Residence, living with families, the field of study, suspected/infected relatives and physical exercise were factors significantly associated with depression. Students who came from rural areas were less likely to develop depression. This finding was supported by the study done in Bangladesh. ${ }^{12}$ This might be due to the difference in information and the implementation of preventive measures. As an example, in an urban area, there was a difficulty for implementing physical distancing due to the condensed population and get access to the daily reports of COVID-19 (death and new cases) which leads to the student's depression. Those students staying with family were four times at risk of developing depression compared with those students who stay alone. This finding was supported by a study conducted in Bangladesh. ${ }^{12}$ This might be due to the fear of infecting and losing their families. Students who engaged in health science-related 
studies had less risk of developing depression compared with students in other fields of studies. This might be due to the healthcare students could have been well-informed on what to expect as the pandemic progresses compared to the students of other fields of studies.

The odds of depression were nearly four times higher among students who have suspected or infected family members/relatives with COVID-19. This finding was supported by a study conducted in China. ${ }^{20}$ This might be due to the fear of losing the beloved one, family, and relatives by death due to COVID-19 or fear of getting an infection from the relatives and becoming ill. Those students who did not perform physical exercise were nearly two times at risk of developing depression compared with their counterparts. This finding was supported by the study conducted in Bangladesh. ${ }^{12}$ This might be due to the effect of physical exercise on psychological and physical health or spending time with physical exercise instead of only thinking about the severity and consequences of the outbreak.

\section{This Study Has Some Limitations}

The study did not include non-graduating class university students. The cross-sectional nature of the study makes it impossible to draw inferences about the direction of relations and it does not show cause and effect relationship among study variables. The study did not incorporate objective measurements that may be prone to reporting bias since it was based on subjective responses.

\section{Conclusion}

More than one-fifth, more than one-third, and nearly twofifths of graduating students had stress, anxiety, and depression in response to the COVID-19 pandemic respectively. Living in an urban area, living with a family, sedentary lifestyle, unable to practice COVID-19 preventive measures, and having a contact history with suspected/confirmed cases increases the risk of developing stress. Living in an urban area, substance use, sedentary lifestyle, and fear of infecting family members increase the risk of developing anxiety. Students who came from an urban area, live with a family, a study in non-health departments, had confirmed/suspected cases in the family, and did not perform physical exercise had a higher odds of developing depression. It is better to develop effective strategies and interventions, follow and order students, train students about self-protection, and establish a psychological crisis intervention team to minimize the psychological impact of the COVID-19 pandemic on graduating class students.

\section{Abbreviations}

AOR, adjusted odds ratio; CI, confidence interval; COVID19, coronavirus disease 2019; DASS, Depression, Anxiety, and Stress Scale; IRB, Institutional Review Board; MERS, Middle East respiratory syndrome; OR, odds ratio; SARS$\mathrm{CoV}$, severe acute respiratory syndrome coronavirus; SPSS, Statistical Package for Social Sciences; UNESCO, United Nation's Educational, Scientific, and Cultural Organization; WHO, World Health Organization.

\section{Data Sharing Statement}

All data are available upon request. The reader could contact the corresponding author for the underlying data.

\section{Ethics Approval and Informed Consent}

Before conducting the study, ethical clearance was obtained from the institutional review board (IRB) of the University of Gondar (Reference number: V/P/RCS/05/ 585/2020). A written permission letter was obtained from the campus dean's office. Participants were informed about the purpose of the study and written informed consent was obtained from them. Confidentiality was maintained by omitting direct personal identifiers on the questionnaire, by using code numbers, storing data locked with a password, and not misuse or wrongfully disclose their information. Participants were also informed that participation was voluntary and they can withdraw from the study participation at any stage if they are not comfortable with the investigation. The investigators prepared a onepage information sheet regarding the purpose and nature of the study. This study complied with the Declaration of Helsinki.

\section{Acknowledgments}

The authors are grateful to the University of Gondar, data collectors, and study participants.

\section{Author Contributions}

All authors made a significant contribution to the work reported, whether that is in the conception, study design, execution, acquisition of data, analysis, and interpretation, or in all these areas; took part in drafting, revising, or critically reviewing the article; gave final approval of the 
version to be published; have agreed on the journal to which the article has been submitted; and agree to be accountable for all aspects of the work.

\section{Funding}

No funding has been received for the conduct of this study and/or preparation of this manuscript.

\section{Disclosure}

The authors report no conflicts of interest for this work.

\section{References}

1. Zu ZY, Jiang MD, Xu PP, et al. Coronavirus disease 2019 (COVID19): a perspective from China. Radiology. 2020;296(2):200490. doi:10.1148/radiol.2020200490

2. John Joseph S, Singh Bhandari S, Ranjitkar S, Dutta S. School closures and mental health concerns for children and adolescents during the covid-19 pandemic. Psychiatr Danub. 2020;32 (2):309-310.

3. WHO. Africa, the First Case of Covid-19 Confirmed in Ethiopia. 2020

4. Ethiopia's unconventional COVID-19 response Arkebe Oqubay, World Economic Forum. 5 June 2020.

5. Brooks SK, Webster RK, Smith LE, et al. The psychological impact of quarantine and how to reduce it: rapid review of the evidence. Lancet. 2020;395(10227):912-920. doi:10.1016/S0140-6736(20) 30460-8

6. Shigemura J, Ursano RJ, Morganstein JC, Kurosawa M, Benedek DM. Public responses to the novel 2019 coronavirus $(2019-\mathrm{nCoV})$ in Japan: mental health consequences and target populations. Psychiatry Clin Neurosci. 2020;74(4):281. doi:10.1111/pcn.12988

7. Lee J. Mental health effects of school closures during COVID-19. Lancet Child Adolesc Health. 2020;4(6):421. doi:10.1016/S23524642(20)30109-7

8. Wu P, Fang Y, Guan Z, et al. The psychological impact of the SARS epidemic on hospital employees in China: exposure, risk perception, and altruistic acceptance of risk. Can J Psychiatry. 2009;54(5):302311. doi:10.1177/070674370905400504

9. Sahu P. Closure of universities due to Coronavirus Disease 2019 (COVID-19): impact on education and mental health of students and academic staff. Cureus. 2020;12(4). doi:10.7759/cureus.7541

10. Salman M, Asif N, Mustafa ZU, et al. Psychological impact of COVID-19 on Pakistani University Students and how they are coping. medRxiv. 2020.

11. Important update on COVID-19 at Bloomfield College, student tests positive. 2020

12. Islam MA, Barna SD, Raihan $\mathrm{H}$, Khan MNA, Hossain MT. Depression and anxiety among university students during the COVID-19 pandemic in Bangladesh: a web-based cross-sectional survey. PLoS One. 2020;15(8):e238162. doi:10.1371/journal. pone. 0238162

13. Ojewale LY Psychological state, family functioning, and coping strategies among students of the University of Ibadan, Nigeria, during the COVID -19 lockdown. 2020.

14. Aylie NS, Mekonen MA, Mekuria RM. The psychological impacts of COVID-19 pandemic among university students in Bench-Sheko Zone, South-west Ethiopia: a community-based Cross-sectional Study. Psychol Res Behav Manag. 2020;13:813. doi:10.2147/ PRBM.S275593
15. Tadesse AW, Mihret S, Biset G, Muluneh A. Psychological impacts of COVID-19 among college students in Dessie Town, Amhara Region, Ethiopia; Cross-sectional Study. 2020.

16. Cao W, Fang Z, Hou G, et al. The psychological impact of the COVID-19 epidemic on college students in China. Psychiatry Res. 2020;287:112934. doi:10.1016/j.psychres.2020.112934

17. Marelli S, Castelnuovo A, Somma A, et al. Impact of COVID-19 lockdown on sleep quality in university students and administration staff. J Neurol. 2020;1-8.

18. Son C, Hegde S, Smith A, Wang X, Sasangohar F. Effects of COVID-19 on college students' mental health in the United States: an interview survey study. J Med Internet Res. 2020;22(9):e21279. doi: $10.2196 / 21279$

19. Wang C, Zhao H. The impact of COVID-19 on anxiety in Chinese University Students. Front Psychol. 2020;11:1168. doi:10.3389/ fpsyg. 2020.01168

20. Wang Z-H, Yang H-L, Yang Y-Q, et al. Prevalence of anxiety and depression symptoms, and the demands for psychological knowledge and interventions in college students during COVID-19 epidemic: a large cross-sectional study. J Affect Disord. 2020;275:188-193. doi:10.1016/j.jad.2020.06.034

21. Sun S, Goldberg SB, Lin D, Qiao S, Operario D. Psychiatric symptoms, risk, and protective factors among university students in quarantine during the COVID-19 pandemic in China. medRxiv. 2020. doi:10.1101/2020.07.13.20152678

22. Odriozola-González P, Planchuelo-Gómez Á, Irurtia MJ, de Luisgarcía R. Psychological effects of the COVID-19 outbreak and lockdown among students and workers of a Spanish university. Psychiatry Res. 2020;113108. doi:10.1016/j.psychres.2020.113108

23. Hamza CA, Ewing L, Heath NL, Goldstein AL. When social isolation is nothing new: a longitudinal study of psychological distress during COVID-19 among university students with and without preexisting mental health concerns. Can Psychol. 2020. doi:10.1037/ cap0000255

24. Sundarasen S, Chinna K, Kamaludin K, et al. Psychological impact of covid-19 and lockdown among university students in Malaysia: implications and policy recommendations. Int $J$ Environ Res Public Health. 2020;17(17):6206. doi:10.3390/ijerph17176206

25. WHO. WHO Global Recommendations on Physical Activity for Health. Geneva: World Health Organization; 2011.

26. Lovibond PF, Lovibond SH. The structure of negative emotional states: comparison of the Depression Anxiety Stress Scales (DASS) with the beck depression and anxiety inventories. Behav Res Ther. 1995;33(3):335-343. doi:10.1016/0005-7967(94)00075-U

27. Asghari MM, Saed F, Dibajnia P, Zangeneh J. Preliminary validation of the depression, anxiety, and stress scales (DASS) in a non-clinical sample. 2008.

28. Hudson CG. Socioeconomic status and mental illness: tests of the social causation and selection hypotheses. Am J Orthopsychiatry. 2005;75(1):3-18. doi:10.1037/0002-9432.75.1.3

29. Al Omari O, Al Sabei S, Al Rawajfah O, et al. Prevalence and predictors of depression, anxiety, and stress among youth at the time of CoViD-19: an online cross-sectional multicountry study. Depress Res Treat. 2020:2020. doi:10.1155/2020/8887727

30. Sahile AT, Ababu M, Alemayehu S, et al. Prevalence and severity of depression, anxiety, and stress during pandemic of COVID-19 among college students in Addis Ababa, Ethiopia, 2020 a Cross-Sectional Survey. Int J Clin Exp Med Sci. 2020;6(6):126.

31. McKenzie K, Murray A, Booth T. Do urban environments increase the risk of anxiety, depression, and psychosis? An epidemiological study. J Affect Disord. 2013;150(3):1019-1024. doi:10.1016/j. jad.2013.05.032

32. Aslan I, Ochnik D, Çınar O. Exploring perceived stress among students in Turkey during the COVID-19 pandemic. Int $J$ Environ Res Public Health. 2020;17(23):8961. doi:10.3390/ijerph17238961 
33. Savage MJ, James R, Magistro D, et al. Mental health and movement behavior during the COVID-19 pandemic in UK university students: prospective cohort study. Ment Health Phys Act. 2020;19:100357. doi:10.1016/j.mhpa.2020.100357

34. Silva LRB, Seguro CS, De Oliveira CGA, et al. Physical inactivity is associated with increased levels of anxiety, depression, and stress in Brazilians during the COVID-19 pandemic: a cross-sectional study. Front Psychiatry. 2020;11:1257. doi:10.3389/fpsyt.2020.565291

35. Pate RR, Sallis JF, Porter KMP. Surveillance of physical activity: actions needed to support new federal guidelines. Am J Public Health. 2020;110(1):87-89. doi:10.2105/AJPH.2019.305443
36. Cortés-Álvarez NY, Pineiro-Lamas R, Vuelvas-Olmos CR. Psychological effects and associated factors of COVID-19 in a Mexican sample. Disaster Med Public Health Prep. 2020;14 (3):413-424. doi:10.1017/dmp.2020.215

37. Otto M, Smits JA. Exercise for Mood and Anxiety: Proven Strategies for Overcoming Depression and Enhancing Well-Being. USA: OUP;2011.

38. Smith JP, Book SW. Anxiety and substance use disorders: a review. Psychiatr Times. 2008;25(10):19.

\section{Publish your work in this journal}

Psychology Research and Behavior Management is an international, peer-reviewed, open access journal focusing on the science of psychology and its application in behavior management to develop improved outcomes in the clinical, educational, sports and business arenas. Specific topics covered in the journal include: Neuroscience, memory and decision making; Behavior modification and management; Clinical applications; Business and sports performance management; Social and developmental studies; Animal studies. The manuscript management system is completely online and includes a very quick and fair peer-review system, which is all easy to use. Visit http://www. dovepress.com/testimonials.php to read real quotes from published authors. 